\title{
Bixa Orellana L Leaf infusion as an Anti-inflammatory Agent in Carrageenan-induced Wistar Rats
}

\author{
Sabrina Munggarani Yusuf, ${ }^{1}$ Enny Rohmawaty, ${ }^{2}$ Rama Nusjirwan ${ }^{3}$ \\ ${ }^{1}$ Faculty of Medicine, Universitas Padjadjaran, ${ }^{2}$ Department of Pharmacology and Therapy, Faculty \\ of Medicine, Universitas Padjadjaran, ${ }^{3}$ Department of Surgery, Faculty of Medicine, Universitas \\ Padjadjaran/Dr. Hasan Sadikin General Hospital, Bandung
}

\begin{abstract}
Background: One of the characteristics of inflammation is swelling or edema. Inflammation can be treated with traditional medicine, such as Bixa orellana L. Bixa orellana L leaf contains flavonoid and tannin responsible for its anti-inflammatory effect. This study was conducted to analyse the ability of Bixa orellana $\mathrm{L}$ leaf infusion (BOLI) to suppress paw edema in carrageenan-induced Wistar rats.

Methods: This study was conducted in the Animal Laboratory of Department of Pharmacology and Therapy Faculty of Medicine Universitas Padjadjaran in October 2012. Bixa orellana L leaves were procured from Lembang, Bandung, and were botanically identified at the Herbarium of Universitas Padjadjaran, Jatinangor. Thirty female Wistar rats were randomly divided into five groups. Group 1 was given $5 \mathrm{~mL}$ aquades as a control, three groups received BOLI with 0,09 g; 0,18 g; and 0,36 g dosage respectively; and group 5 was given $0,9 \mathrm{mg}$ diclofenac. At 1 hour after treatment, all rats were induced by carrageenan injection subcutaneously. Paw edema changes were quantified at $0,1,2,3,4,5,6$, and 24 hour afterwards. Data were analysed using Kruskal-Wallis and Mann-Whitney test
\end{abstract}

Results: Based on paw edema inhibition percentage, $0.18 \mathrm{~g}$ of BOLI was shown most effective (16.97\%) compared to $0.09 \mathrm{~g}(10.96 \%)$ and $0.36 \mathrm{~g}(7.50 \%)$. Interestingly, no significant differences of anti-inflammatory effect were observed between groups that were treated with $0,18 \mathrm{~g}$ of BOLI and diclofenac $(\mathrm{p}>0,005)$.

Conclusions: The BOLI with effective dosage $0.18 \mathrm{~g}$ (equivalent with $200 \mathrm{~g}$ bodyweight/day) suppress inflammation comparable to diclofenac. [AMI.2014;1(2):60-4]

Keywords: Anti-inflammatory, Bixa orellana L leaf, edema

\section{Infusa Daun Kesumba (Bixa Orellana L) sebagai Anti Inflamasi pada Tikus Wistar yang Diinduksi Carrageenan}

\begin{abstract}
Abstrak
Latar Belakang: Salah satu ciri khas dari peradangan atau inflamasi adalah adanya pembengkakan atau edema. Peradangan dapat diobati dengan obat tradisional, seperti Kesumba (Bixa orellana). Daun Kesumba diketahui mengandung flavonoid dan tanin yang berfungsi sebagai anti-inflamasi. Penelitian ini dilakukan untuk menganalisis kemampuan infusa daun kesumba (Bixa orellana) (BOLI) dalam mengurangi edema tungkai pada kaki tikus Wistar yang diinduksi Carrageenan.

Metode: Penelitian ini dilakukan di Laboratorium Hewan Departemen Farmakologi dan Terapi di Rumah Sakit Umum Dr. Hasan Sadikin Bandung pada bulan Oktober 2012. Daun Kesumba (Bixa Orellana L) diperoleh dari Lembang, Bandung, dan diidentifikasi botani di Herbarium Universitas Padjadjaran, Jatinangor. Tiga puluh tikus Wistar betina secara acak dibagi menjadi lima kelompok. Kelompok 1 diberi $5 \mathrm{~mL}$ aquades sebagai kontrol, tiga kelompok menerima BOLI dengan 0,09 g; 0,18 g; dan masing-masing 0,36 g dosis; dan kelompok 5 diberi $0,9 \mathrm{mg}$ diklofenak. Pada 1 jam setelah pengobatan, semua tikus diinduksi oleh subkutan injeksi karagenan. Perubahan edema tungkai diukur pada 0, 1, 2, 3, 4, 5, 6, dan 24 jam sesudah pengobatan. Data dianalisis dengan menggunakan Kruskal-Wallis dan uji Mann-Whitney.

Hasil: Berdasarkan persentase pengurangan edema tungkai, kelompok 0,18g BOLI terlihat paling efektif $(16,9 \%)$ dibandingkan dengan $0,09 \mathrm{~g}(10,9 \%)$ dan $0,36 \mathrm{~g}(7,5 \%)$. Tidak ada perbedaan yang signifikan dari
\end{abstract}

Correspondence: Sabrina Munggarani Yusuf, Faculty of Medicine, Universitas Padjadjaran, Jalan Raya BandungSumedang Km.21, Jatinangor, Sumedang, Indonesia, Phone: +6281513130450, Email: sabrinamyusuf@yahoo.com 
efek anti-inflamasi yang diamati antara kelompok-kelompok yang diobati dengan 0,18 g BOLI dan diklofenak (p>0.005).

Simpulan: Infusa Daun Kesumba (BOLI) dengan dosis efektif 0,18 g (setara dengan $200 \mathrm{~g}$ berat badan / hari) menekan peradangan sama baik dibandingkan dengan diklofenak. [AM],2014;1(2):60-4]

Kata kunci: anti-inflamasi, daun kesumba (Bixa orellana L), edema

\section{Introduction}

Inflammation is a protective response invoked in organisms towards alteration in normal tissues. It has five main characteristics, which are rubor (redness), tumor (swelling), calor (heat), dolor (pain), and functiolaesa (loss of function). Chronic inflammation can cause rheumatoid arthritis, atherosclerosis, and tuberculosis. Therefore, anti-inflammatory drugs, both steroidal and non-steroidal, play a pivotal role in taking the response under control. ${ }^{1}$

Bixa orellana L, the so-called "lipstick tree" from Bixaceae family, has been approved safe for human consumption by the Food and Drug Administration (FDA) of the USA. It is beneficial intreating fever, stomachache, sore throat, burn injury, and epilepsy pertaining to its anti-inflammatory effect. ${ }^{3}$ A Previous study) using Bixa orellana L leaf extract proved flavonoid and tannin in favor of that advantage. Moreover, there are some other chemical compounds found within Bixa orellana L leaf, for instance sterol, saponin, and ishwarane. ${ }^{4}$ This study was conducted to analyse the anti-inflammatory effect of Bixa orellana L. leaf infusion (BOLI) for an easier homebased production. Wistar rats was induced by carrageenan to generate paw edema. Efficacy of BOLI compared to diclofenac and the most effective dosage were determined.

\section{Methods}

This experiment was conducted in the Animal Laboratory of Department of Pharmacology and Therapy in Dr. Hasan Sadikin General Hospital Bandung in October 2012. Bixa orellana L. leaves were procured from Lembang, Bandung, and were botanically identified at the Herbarium of Universitas Padjadjaran in Jatinangor. Thirty healthy female Wistar rats (2-3 months old) weighing $\pm 200-50$ g were used as subjects. All rats were housed in homogenous temperature and darklighted cycle for 7 days with ad libitum access to food and drink. The rats were subsequently fasting for the next 24 hours to promote optimal inflammatory response. The procedure was done in accordance with the Russel and Burch's principle of humane experimental techniques: reduction, refinement and replacement (3R). ${ }^{5}$

The BOLI was prepared from dried Bixa orellana L. leaves weighed according to dosage and $100 \mathrm{~mL}$ of water for every treatment group. Mixed raw material was heated in an infusion pan for 15 minutes after the temperature reached $90^{\circ} \mathrm{Cwhile}$ being stirred every 5 minutes. Next, BOLI was filtered usingflannel fabric.Thirty millilitersof BOLIwere used for each rat in the treatment group receiving as much as $5 \mathrm{~mL}$. Extra water was added to gain BOLI volume as required. ${ }^{6}$

At one hour before treatment, basal right paw volume was quantified with a pletysmometer until lateral maleoluswhich was marked with a label sticker. Wistar rats were randomly divided into five groups. Group 1 served as the negative group and was given 5 $\mathrm{mL}$ aquades, three groups received BOLI with 0.09 g; 0.18 g; and 0.36 g dosage respectively; and last group positive group was given $0.9 \mathrm{mg}$ diclofenac. All treatments were given orally. An hour afterwards, edema was induced by carrageenan injection subcutaneously in sub plantar area of the posterior right paw. In order to alleviate the pain, all rats were locally anesthesized using $20 \mathrm{mg} / \mathrm{kg} \mathrm{BW}$ of ketamine hydrochloride intraperitoneally prior to subcutaneous injection.

Paw edema volume changes were determined at 1, 2, 3, 4, 5, 6, and 24 hour (V1, V2, V3, V4, V5, V6, and V24) after treatment. Moreover, the efficacy of each treatment group to suppress paw edema was calculated compared to negative group. Results were classified into stadium 1 (\% edema inhibition $<10 \%$ or poor), stadium 2 (\% edema inhibition 10-15\%or moderate), and stadium 3 (\% edema inhibition $>15 \%$ or excellent). Data were statistically analysed using KruskalWallis and Mann-Whitney non-parametric tests when data distribution was not in normal distribution. The $\mathrm{P}$ value $\leq 0.05$ was set to show significant difference. 


\section{Results}

As expected, negative group had the largest paw edema changes at 3 hour after treatment $(1.36 \mathrm{~mL})$ and the smallest paw edema changes were seen in group of rats given $0.18 \mathrm{~g}$ of BOLI at 24 hour after treatment $(0,83 \mathrm{~mL})$ (Table 1$)$.

The group given $0.18 \mathrm{~g}$ of BOLI had the smallest mean paw edema changes. Data were then conversed into percentage. Paw volume in all groups gradually increased at 1 to 3 hour time point, and then started to fall afterwards. This proved the efficacy of carrageenan to optimally induce edema-forming effect at the first two hours after injection, after which was inhibited by both treatment groups and positive group.

Kruskal-Wallis test was exerted to identify the effect of various dosage of BOLI towards mean paw volume. Paw edema was significantlysuppressed at 2 and 6 hour after treatment $(\mathrm{p}<0.05)$.

When compared to negative group, significant differences were not shown solely in group given $0.09 \mathrm{~g}$ of BOLI. In addition, significant difference among three dosages of BOLI $(p<0.05)$ was merely seen between groups given $0.18 \mathrm{~g}$ and $0.36 \mathrm{~g}$ of BOLI at 4 and 6 hour time points.

The group treated with $0.18 \mathrm{~g}$ of BOLI had the biggest inhibition (16.97\%) followed closely by diclofenac $(13.79 \%)$. Both groups did not show significant differences when compared using Mann-Whitney test.

\section{Discussion}

Anti-inflammatory effect in rats was examined by calculating suppression of paw edema as the simplest chemical method in the Animal Laboratory of the Department of Pharmacology and Therapy. Carrageenan was admintered as the inducer of inflammation due to its acute, non-immune, well-studied, and easily produced response. The efficacy of carrageenan was related to its biphasic course of reaction (Figure 1). The first phase was mediated by histamine, serotonin, 5-hydroxytryptamine, and bradykininrelease lasting for 2 hours.7 The inability of Nonsteroidal Anti-inflammatory Drugs (NSAIDs), such as diclofenac, to intervene was because this phase did not comprise the activation of cyclooxygenase (COX) pathway. On the contrary, the second phase being manipulated was carried out by prostaglandin, protease, and lysosome production for as long as 3-5 hours, or even 24 hours after injection. ${ }^{8}$

Enhancement of paw edema at 1-3 hour time interval was also observed in the group treated with diclofenac. Due to its half life (1-2 hours), diclofenac attained optimal antiinflammatory effect at 2-3 hours after oral administration. It suppressed nitric oxide (NO) by altering the uptake and release of fatty acid responsible for the syntesis of arachidonic acid, the precursor of COX. ${ }^{2,9}$

Identical response also occured in the treatment groups. This can be explained by the ability of chemical constituents in BOLI, flavonoid and tannin, to block the second phase of carrageenan-induced inflammatory reaction.While flavonoid inhibited the production of COX-2 and inducible nitric oxide synthase (iNOS), tannin helped decrease reactive oxygen species (ROS) and free radicals concentration in the blood through its oxidation. ${ }^{10,11,12}$ Tannin is also capable of forming complex with protein, polysaccharide, alkaloid, nucleic acid, and mineral. ${ }^{13}$ Therefore, further study should be conducted to examine the effect of tannin administration topically to accelerate wound healing.

Different dosages of BOLI showed significantly different anti-inflammatory effect at 2 and 6 hour. After administration, flavonoid metabolites obtained maximal serum concentration at 1 hour and last for 4 hours. During that period, flavonoid concentration in

Table 1 Paw Edema Volume Changes at Various Time Point

\begin{tabular}{cccccccccc}
\hline Group & V0 & V1 & V2 & V3 & V4 & V5 & V6 & V24 & $\begin{array}{c}\text { Mean + } \\
\text { SD }^{*}\end{array}$ \\
\hline 1 & 0.66 & 1.15 & 1.28 & 1.36 & 1.31 & 1.33 & 1.25 & 0.96 & 1.16 \\
2 & 0.61 & 1.05 & 1.16 & 1.25 & 1.13 & 1.11 & 1.08 & 0.90 & 1.03 \\
3 & 0.56 & 1.00 & 1.01 & 1.16 & 1.06 & 1.11 & 0.98 & 0.83 & 0.96 \\
4 & 0.61 & 1.01 & 1.10 & 1.30 & 1.26 & 1.23 & 1.18 & 0.91 & 1.07 \\
5 & 0.68 & 1.00 & 1.00 & 1.20 & 1.18 & 1.11 & 1.05 & 0.90 & 1.01 \\
\hline
\end{tabular}




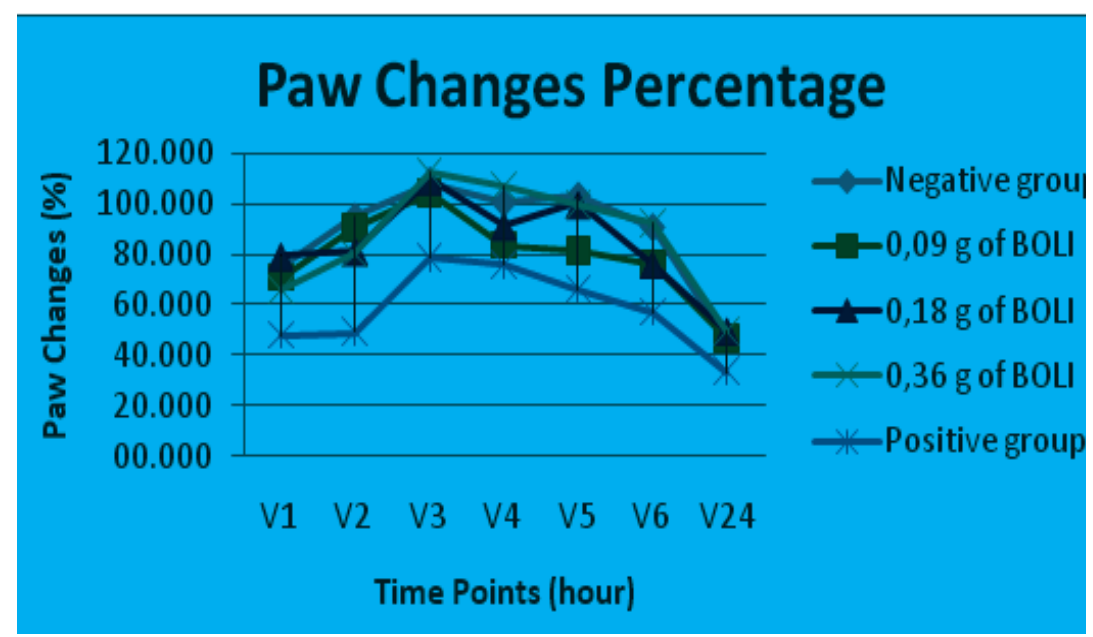

\section{Figure1 Paw Changes Percentage at Every Time Point}

blood plasma is minimally altered. ${ }^{14}$ Factors that affect the time required for flavonoid to achieve its peak serum concentration include variation of food matrix and metabolism enzymes, causing disparities among efficacy in polyphenol absorption. ${ }^{15}$ On the other hand, it was assumed that the elimination of half life of BOLI was 6 hours after treatment with carrageenan.

There was no significant differences between the group with $0.09 \mathrm{~g}$ of BOLI and the negative group. This might be explained due to dosage that was insufficient to attain optimal serum concentration. ${ }^{14}$ When comparing effects among treatment groups, only the group with $0.18 \mathrm{~g}$ and $0.36 \mathrm{~g}$ of BOLI displayed significant differenceat 4 and 6 hour after treatment. The group with $0.18 \mathrm{~g}$ of BOLI was most effective. Inefficiency of $0.36 \mathrm{~g}$ of BOLI might have occured due to the waning of its anti-inflammatory effect. However, this assumption should be verified in further studies.

Mean paw edema inhibition percentage clearly showed efficacy when groups were compared. No significant differences were found between $0.18 \mathrm{~g}$ of BOLI and the positive group. Thus, $0.18 \mathrm{~g}$ of BOLI was able to prevent paw volume from increasing which was comparable to diclofenac, rating stadium 3 . On the contrary, the group with $0.09 \mathrm{~g}$ of BOLI was classified as stadium 2 and the group with $0,36 \mathrm{~g}$ of BOLI was inclusive to stadium 1 as an anti-inflammatory agent.

These results provided scientific evidence for the benefit of Bixa orellana L. leaf used to counter disruptive effect of inflammation, in harmony with the prior study conducted by
Keong et al. ${ }^{4}$ using extract of Bixa orellana L. leaf. Bixa orellana L. leaf in the form of both extract and infusion showed comparable antiinflammatory effect because the ratio between the plantand the diluent did nothave significant impact to the chemical compounds contained within. In fact, chemical compositions in the leaf are mainly dependent on the temperature and duration of the extraction process.

As conclusion, our present data suggested that Bixa orellana L. leaf infusion has an antiinflammatory effect that are comparable to diclofenac with the most effective dosage $0.18 \mathrm{~g}$ equivalent $200 \mathrm{~g}$ body weight/day. Further studies may clarifty its potential as a topical anti-inflammatory agent as well as its probable toxic effect.

\section{References}

1. Kumar V, Abbas A, Fausto N, editors. Pathologic basis of disease. 8th ed. Philadelphia: Saunders Elsevier; 2010.

2. Katzung BG, Masters SB, Trevor AJ, editors. Basic and clinical pharmacology. 11th ed. New York: Mc.Graw-Hill Companies, Inc.; 2009.

3. Chengaiah B, Mallikarjuna KR, Kumar KM, Alagusundaram M, Chetty CM. Medicinal importance of natural dyes - a review. Int J PharmTech Res. 2010;2(1);144-54.

4. Yoke Keong Y, Arifah AK, Sukardi S, Roslida AH, Somchit MN, Zuraini A. Bixa orellana leaves extract inhibits bradykinin-induced inflammation through suppression of nitric oxide production. Med Princ Pract. 2011;20(2):142-6.

5. Balls M. The principles of humane 
experimental techniques: timeless insights and unheeded warnings. ALTEX;2010;27 (Special Issue):19-23

6. Syamsuni HA. Ilmu resep. Jakarta: Penerbit Buku Kedokteran EGC; 2005.

7. Morris CJ. Methods in molecular biology. In: Paul G. Winyard, Derek A. Willoughby, editors. 2003 inflammation protocols. New Jersey: Humana Press; 2003. p. 115-21.

8. Suralkar AA, Sarda PS, Ghaisas MM, Thakare VN, Deshpande AD. In-vivo animal models for evaluation of anti-inflammatory activity. Pharmainfo.net [Online Journal] 2008 [cited 2012 April 28]. Available at: http://www.pharmainfo.net/reviews/ vivo-animal-models-evaluation-antiinflammatory-activity

9. Hardman JG, Limbard LE, editors. Goodman \& Gilmans: the pharmacological basis of theurapeutics. 10th ed. New York: McGraw-Hill Companies, Inc.; 2001.

10. Hämäläinen $M$, Nieminen $R$, Vuorela $\mathrm{P}$, Heinonen M, Moilanen E. Antiinflammatory effects of flavonoids: genistein, kaempferol, quercetin, and daidzein inhibit STAT-1 and NF-kappaB activations, whereas flavone, isorhamnetin, naringenin, and pelargonidin inhibit only NF-kappaB activation along with their inhibitory effect on iNOS expression and
NO production in activated macrophages. Mediators Inflamm. 2007;2007:45673.

11. Jeffers MD. Tannin as anti-inflammatory agents [dissertation]. Oxford, Ohio: Miami University; 2006.

12. Liang YC, Huang YT, Tsai SH, Lin-Shiau SY, Chen CY, Lin JK. Suppression of inducible cyclooxygenase and inducible nitric oxide synthase by apigenin and related flavonoids in mouse macrophages. Carcinogenesis. 1999;20(10);1945-52.

13. Frutos $P$, Hervás G, Giràldez FJ, Mantecón AR. Tannins and ruminant nutrition. Span J Agric Res. 2004;2(2);191-202.

14. Miyake Y, Sakurai C, Usuda M, Fukumoto S, Hiramitsu M, Sakaida K, et al. Difference in plasma metabolite concentration after ingestion of lemon flavonoids and their aglycones in humans. J Nutr Sci Vitaminol (Tokyo).2006;52(1);54-60.

15. Manach C, Williamson G, Morand C, Scalbert A, Rémésy C. Bioavailability and bioefficacy of polyphenols in humans. Am J Clin Nutr. 2005:81(1 Suppl); 230S-42S.

16. Ye Q, Liang Y, Lu J. Effect of different extracting methods on quality of Chrysanthemum morifolium ramat infusion. Asia Pac J ClinNutr. 2007;16 Suppl 1:183-7. 